\title{
Immunological aspects of food allergy
}

\section{By E. Bleumink, Department of Dermatology, State University Groningen, 59 Oostersingel, 9713 EZ Groningen, The Netherlands}

Food allergy is a clinical manifestation of an immunological process in which specific antibodies or sensitized $T$-lymphocytes interact with food constituents. The reaction may occur after ingestion of the particular food, after inhalation or by epicutaneous contact.

A distinction must be made between food allergy, which is an immunological process, and other disorders provoked by foods. Adverse reactions to foods and their ingredients may be divided into the following categories:

1. Hypo-intoxications and intoxications from food additives (tartrazine, benzoates), natural components (oxalate, goitrogens, cholinesterase inhibitors) and micro-organisms (bacterial toxins, mycotoxins).

2. Intolerance phenomena or idiosyncrasies, or both, due to inborn errors: examples are lactose intolerance, gluten-induced enteropathies, hyperlipoproteinaemia, disorders of amino acid metabolism and hereditary haemolytic anaemia. The latter may occur in persons with glucose-6phosphate dehydrogenase deficiency after the consumption of currants, gooseberries or the beans of Vicia faba.

3. Allergic reactions mediated either by immunoglobulins (IgE, IgM, IgG) or sensitized T-lymphocytes.

1

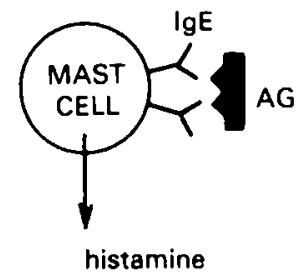

III

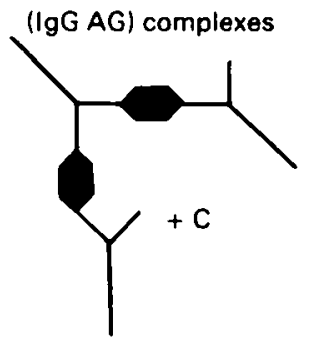

II

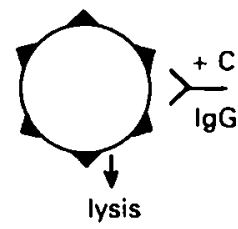

IV

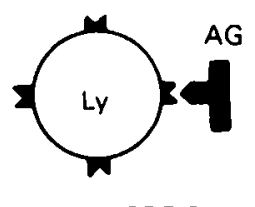

MIF,SRF,CF

Fig. I. Diagrammatic illustration of the four types of allergic reactions. AG, allergen; C, complement; Ly, lymphocyte; MIF, migration inhibition factor; SRF, skin reactive factor; CF, chemotactic factor. 
4. Pseudo-allergic reactions caused by histamine (old cheese), histamine liberators (in strawberries or shell fish and causing urticaria) or plant lectins. The latter substances, also called phytohaemagglutins, blastomitogens or plantagglutinins, are capable of activating T-lymphocytes non-specifically. Lectins are present in soya bean, peas, beans, lentils, wheat and other cereals.

5. Psychological effects.

\section{Division of allergic reactions}

Allergic reactions have been conveniently classified (Coombs \& Gell, 1975) into four types (Fig. 1 ), although in any particular disease process more than one mechanism may operate.

Type I: atopic or anaphylactic phenomena. These reactions occur when an allergen (the responsible agent or antigen) combines with reaginic (IgE) antibodies at the surface of mast cells or basophilic leucocytes. Reaginic allergy is known to be familial: if one parent is affected the offspring has a $50 \%$ chance of being affected and if both parents are affected this rises to $66 \%$. Approximately $10 \%$ of the population in Europe and North America have an atopic constitution and it is the most common allergic disorder attributable to foods.

Type II: cytotoxic phenomena. The symptoms are elicited by reactions between immunoglobulins of the IgG class and antigens which form an integral part of, or become attached to, the surface of the cell; complement (one of the mediator systems in blood) is involved. So far there is little evidence that cytotoxic reactions operate in food allergy.

Type III: arthus type or immune-complex reactions. Reactions occur between soluble or microparticulate antigens and complement-fixing antibodies, which form antigen/antibody/complement complexes. In the tissues they increase capillary permeability, the influx of phagocytes, the release of lysosomal enzymes and consequently tissue destruction.

Controversy exists about the importance of type III reactions in food allergy.

Type IV: cell-mediated immune reactions or delayed allergy. These reactions involve the interaction between antigen and antigen-sensitive T-lymphocytes, leading to the release of soluble mediators or lymphokines. The most familiar type IV reaction is the tuberculin (Mantoux) skin test, while the best-recognized clinical condition is contact dermatitis. Epicutaneous contact with low-molecular-weight food constituents may lead to this type of reaction.

\section{Local immunity of the digestive tract}

The whole of the digestive tract is lined by epithelium in close contact with a strongly developed lymphoid system and over $90 \%$ of lymphoid cells secrete IgA. Two IgA molecules can assemble with a secretory component to give s-IgA, which can coat micro-organisms and food antigens. This may prevent absorption of the vast array of food antigens from the digestive tract and thereby prevent both overloading the systemic immune systems and development of undesirable allergic responses. In the absence of $\operatorname{IgA}$, such as occurs physiologically at the beginning of 
Table I. Properties of immunoglobulins

Molecular weight

Serum concentration $(\mathrm{mg} / \mathrm{r} 00 \mathrm{ml})$

IgE IgG IgA IgM IgD

Placental passage

Complement fixation

Binding to mast cells

Involved in allergic reactions

$\begin{array}{lllll}188100 & 160000 & 170000 \quad 900000 & 184000\end{array}$

$\begin{array}{ccccc}0.01 & 1200 & 150 & 80 & 3 \\ - & + & - & - & - \\ - & + & - & + & - \\ + & ( \pm) & - & - & - \\ ++ & + & - & + & -\end{array}$

life or pathologically in IgA deficiency, IgG, IgM or IgE induction by food constituents will be enhanced (Table $\mathrm{r}$ ).

In addition to the presence of s-IgA in gut mucosa, antibodies of IgM, IgG and IgA to food antigens are found in the peripheral blood of a great many individuals. The frequency with which such antibodies are formed, suggests that this is a normal physiological process and it is only in exceptional cases that circulating antibodies, for example, to milk, egg and wheat proteins, play a role in the aetiology of gastrointestinal symptoms (Freier, 1973; May \& Block, 1978; Bleumink, 1979; Visakorpi, 1979).

Comprehensive studies have indicated that several factors may influence the production of antibodies to dietary protein. Young infants more readily form precipitating (IgG) antibodies to food proteins than those in other age groups (Anderson \& Schloss, 1923) but the quantity of detectable antibodies decreases with increasing age (Bleumink, 1979). This decrease is attributable to a change in the permeability of the gut to dietary proteins and to more adequate proteolysis with increasing age.

In patients with gastrointestinal diseases, the concentration of circulating antibodies to milk, wheat and egg protein is often very high. Patients with coeliac disease, aphthous ulcer, ulcerative colitis and idiopathic steatorrhoea are particularly liable to show high concentrations of antibodies to wheat and cows' milk antigens (Bleumink, 1979). The high levels of antibody are probably an epiphenomenon due to damage of the intestinal wall allowing food antigens to enter the mucosa.

\section{Atopic food allergy}

Pathogenesis of atopy. Many of the common allergic diseases in humans belong to the group designated by Coca ( 1942 ) as atopy ('strange disease'). This is a type of allergic sensitization which is partly hereditary and which leads to clinical symptoms of asthma, rhinitis, atopic dermatitis and, in the more acute cases, of urticaria and angioedema. The symptoms are sometimes associated with gastrointestinal complaints such as diarrhoea and vomiting. The immunoglobulin involved is IgE (reagin), a skin-sensitizing or homocytotropic antibody. The socalled short-term, sensitizing IgG (Parish, I97I), $\operatorname{IgG}_{4}$, has also been found to play a role in atopic (type I) reactions.

IgE-producing plasma cells are present in respiratory and gastrointestinal mucosa (in the lamina propria) and are particularly abundant in the tonsils and 
adenoids; in spleen and subcutaneous lymph nodes only small amounts are detected. IgE is an early-produced immunoglobulin and may play a role in the local defence (like IgA), for example in parasitic-worm infections. For each antigen (allergen), plasma cells synthesize and secrete specific IgE molecules; allergies are thus specific because the $\operatorname{IgE}$ is specific. When specific $\operatorname{IgE}$ molecules are synthesized, they move through the bloodstream and bind to basophilic leucocytes in blood and mast cells in the dermis, the respiratory system and the digestive tract (particularly the oesophagus). The surface of the mast cells and basophils has a great many receptors (c. I00 000) for the Fc part of IgE molecules. On re-exposure the allergen reacts with IgE on the mast cell surface (Fig. I). The IgE-allergen reaction triggers a sequence of events which ultimately lead to the release of preformed mediators in the surrounding tissue: histamine, heparin, a proteolytic enzyme, and factors which activate blood platelets and attract eosinophilic and phagocytic white blood cells (Table 2). The activation of mast cells also leads to the synthesis of prostaglandins and leucotrienes. Each of these mediators contributes in its own way to the clinical symptoms observed: the dilation of small blood vessels and vasopermeation of water and plasma components, the secretion of mucus, contraction of smooth muscle in the airways and intestine and the stimulation of nerve endings in the skin, resulting in itching or pain.

Atopic hypersensitivities are observed in response to a great number of inhalants (pollen, house dust, human and animal dandruff, fungi) and to various common foods like milk, eggs and fruits. Atopic people as a rule are allergic to several substances. The patterns of allergies differ from patient to patient but in adult life nearly all people who manifest atopic diseases are sensitive to human dandruff and house dust. During the first years of life, clinical hypersensitivities to food are common but often the child 'outgrows' his hypersensitivity (Dannaeus \& Inganäs, I98I). In adults, allergic reactions to foods are rare and positive reactions to food extracts, as a rule, are seen in combination with reactions to inhalant allergens.

Tests for atopic food allergy. The diagnosis of food allergy often rests upon the observation of symptoms after repeated challenges, following periods when the

Table 2. Allergic reactions elicit the release of various active components (mediators)

\begin{tabular}{|c|c|c|c|}
\hline $\begin{array}{l}\text { Allergic } \\
\text { reaction } \\
\text { type }\end{array}$ & Recognition by & $\begin{array}{l}\text { Primary } \\
\text { effector } \\
\text { cell }\end{array}$ & Mediators \\
\hline I & Cell-bound IgE & $\begin{array}{l}\text { Mast cell, } \\
\text { basophil }\end{array}$ & $\begin{array}{l}\text { Histamine, kinins } \\
\text { leukotrienes, } \text { PGs }^{\bullet}\end{array}$ \\
\hline III & $\begin{array}{l}\text { Circulating IgG } \\
\text { and IgM }\end{array}$ & $\begin{array}{l}\text { Neutrophil, } \\
\text { platelet }\end{array}$ & $\begin{array}{l}\text { Complement components } \\
\text { (anaphylatoxins), } \\
\text { kinins PGs }\end{array}$ \\
\hline IV & $\begin{array}{l}\text { T-lymphocyte } \\
\text { surface receptor }\end{array}$ & $\begin{array}{l}\text { Small } \\
\text { lymphocyte }\end{array}$ & Lymphokines, $\mathrm{PGs}^{\bullet}$ \\
\hline
\end{tabular}

-Prostaglandins, thromboxanes. 
patient is symptom-free on a diet in which the suspected food is eliminated; in addition, skin tests and serum $\operatorname{IgE}$ analyses may be used. Skin tests are performed with standardized extracts of foods: $0.1 \mathrm{ml}$ or less of diluted solutions are injected intradermally and the reactions are assessed after $10-20 \mathrm{~min}$ by measuring the wheal and erythema response. Specific IgE levels are measured with the radioallergen sorbent test (RAST) and are reported to have a good correlation with provocation methods and skin testing (Aas \& Lundkvist, I973; Hoffman \& Haddad, 1974; Chua et al. 1976; Dannaeus et al. 1977; Wraith et al. 1979; Lessof et al. I 980$)$.

Foods involved in atopy. Although any foodstuff may be considered as potentially allergenic, some foods are notorious, partly because they are frequently encountered and partly because of a high content of allergenic material. Cows' milk, hens' eggs and fish seem to be the most potent sensitizers, followed by some fruits (tomatoes, oranges and bananas), meat, nuts, chocolate, cereals and peanuts; atopic reactions to vegetables (peas, spinach and potatoes) are rare (Aas, 1966; Hedström, 1958; Lehmus \& Roine, 1958; Gonzalez de la Requera et al. 1971; Gerrard et al. 1973; Wraith et al. 1979; Fries, 1982). Allergies to foods often are found in combination with other atopic hypersensitivities (May \& Block, 1978; Wraith et al. 1979; Lessof et al. 1980). For example, individuals who are allergic to bananas, as a rule, will be allergic to inhalants or other foods as well.

The pattern of food hypersensitivities found in an individual or group is, of course, a reflection of their food habits. Fish allergy, particularly to cod, is common in Norway (Aas, 1966). The incidence of hypersensitivities to soya bean is high in individuals who use this as a substitute because of a milk allergy (May \& Alberto, 1972). Gerrard and co-workers (1973) observed that $20 \%$ of one group of milkallergic infants had become allergic to soya bean, whereas in other groups no soya allergy was observed. Horesh (1972) pointed to the importance of buckwheat sensitivity in children in North America where the flour is employed for making griddle cakes and waffles. He tested 500 consecutive allergic patients, living in Cleveland, Ohio: thirty-seven showed positive skin tests while six $(\mathrm{I} \cdot 2 \%)$ were clinically sensitive to buckwheat. They had asthma, urticaria, angioedema and rhinitis after contact with the allergen both as an ingestant and as an inhalant. This allergen also seems to be important in Japan, but in many other countries no buckwheat hypersensitivities have been observed.

Properties of atopic allergens from foods. In the last 15 years, attempts have been made to characterize the allergenic compounds in foods; the most important results are shown in Table 3. The amounts and biological activities of the major allergenic fractions differ considerably. Foodstuffs to which severe reactions are commonly observed (e.g. fish and eggs), contain large amounts of active material; the skin reactivity of these two allergens is also much higher than that of betalactoglobulin and those of many inhalant allergens (Bleumink, 1970; Berrens, 1971).

The molecular weights of the active components are of the same order of magnitude, ranging from 14500 for the allergen fraction from cod to 36000 for the 


\section{Table 3. Properties of major allergenic fractions of some foods"}

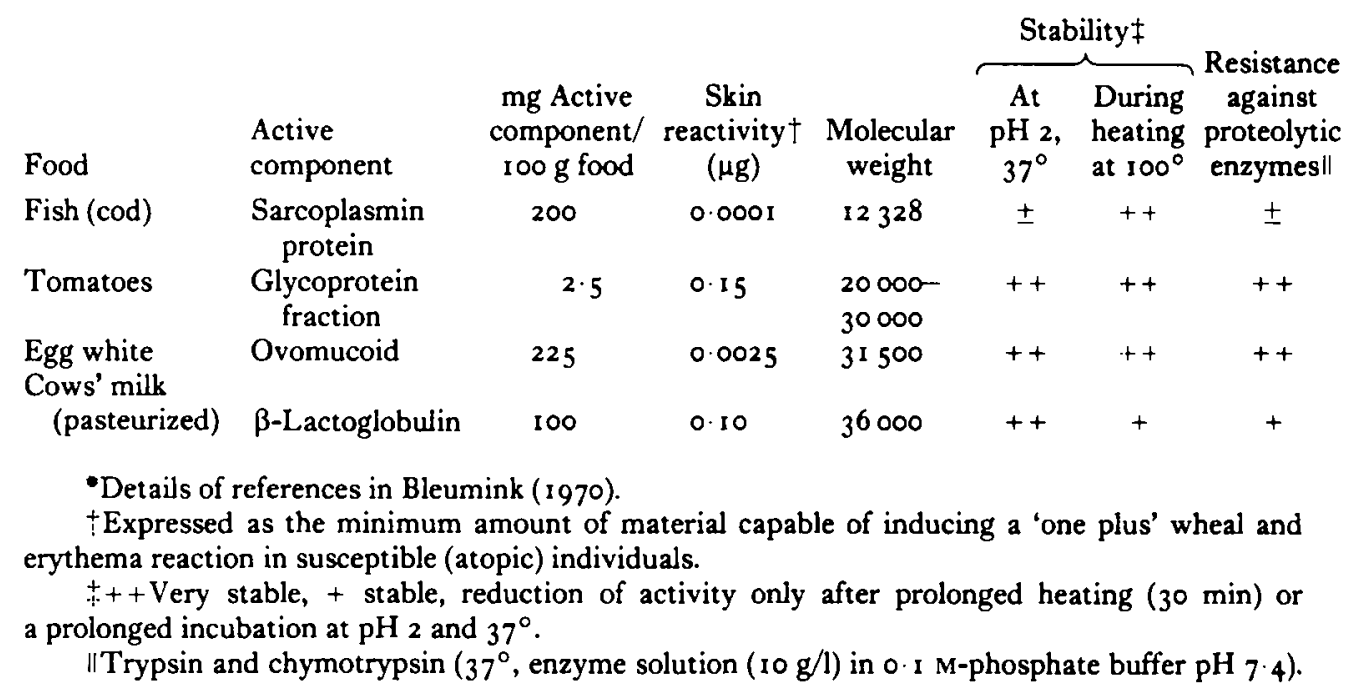

beta-lactoglobulin of cows' milk. The molecular weights of inhalant allergens identified so far fall in the same range (Bleumink, 1970; Berrens, 1971; Stanworth, 1973); apparently, allergenic activity is narrowly restricted to (glyco)-proteins with a molecular weight of approximately I $5000-35000$.

The active protein fractions are stable against heat treatments and some resist the action of proteolytic enzymes (Bleumink, 1970; Wüthrich \& Schwarz-Speck, 1970). The active principles from tomatoes and fish are, for example, not inactivated by heating. The allergen in eggs remains active after boiling and bovine beta-lactoglobulin has been shown to be one of the most stable milk proteins. The tomato allergen resists the action of trypsin and chymotrypsin, and Prausnitz \& Küstner ( $192 \mathrm{I}$ ) presented early evidence that incubation of the active fraction from fish (haddock) with trypsin or pepsin did not lead to a marked decrease of activity. Ovomucoid, the skin-reactive fraction in eggs, inhibits the proteolytic activity of trypsin, and egg white contains a chymotrypsin inhibitor (ovoinhibitor). The active allergenic fraction from pasteurized milk is only slightly susceptible to proteolytic enzymes. These findings imply that the skin-reactive components of foodstuffs will have a good chance of reaching the circulation unaltered after oral digestion, even after heat-processing of the foods in question. Thus normal food processing and household handling will not lead to inactivation of the atopic allergens present in milk, eggs and fish.

\section{Prevention of atopic reactions}

The risk of developing allergic symptoms to foods is greater in early infancy than later in life. The large intake of food proteins in relation to body-weight and the increased permeability of the gut may explain why most infants are more prone to develop antibodies to antigenic materials in foods than adults. All infants display 
a humoral immune response to food antigens (particularly milk and egg proteins) of the IgG, IgA and IgM classes (Dannaeus et al. 1977, 1978; Dannaeus \& Inganäs, 1981) and, in children with an atopic constitution, early exposure can induce the production of $\operatorname{IgE}$ as well. Therefore, avoidance of allergen contact in infants with an atopic constitution (one or both parents having symptoms of asthma, rhinitis or atopic dermatitis) has been suggested. In a prospective study (Matthew et al. 1977) infants of allergic parents were either subjected to an allergen-avoidance regimen from birth for 6 months or managed conventionally. It was found that the group on the allergen-avoidance regimen had less eczema at 6 months and I year; they also had a lower mean serum IgE level.

Taylor et al. (1973) reported that infants born of atopic parents may have a transient IgA deficiency at 3 months of age which could predispose them to atopic disorders later in life. Kaufman \& Frick ( $198 \mathrm{I}$ ) studied ninety-four infants of allergic mothers from birth until nearly 2 years of age and found that breast-fed infants were less likely to develop asthma than those who were bottle-fed. The secretory IgA in breast-milk is thought to afford protection against allergic reactions.

It is uncertain whether sensitization to foods may be prevented by short-term avoidance or only deferred until the foods are ultimately encountered. Proteins can penetrate the intestinal barrier at any age but immunity may not be attainable irrespective of age.

\section{Non-atopic food allergy}

In human beings, severe shock reactions may sometimes be observed after ingestion of foods, especially of milk, eggs, fish and shell fish. The reactions range from prostration, circulatory failure and pulmonary congestion to complete and immediate collapse. Although these reactions are rare, they constitute a highly significant risk for the patient. Only a very small amount of food may be needed to produce sudden alarming symptoms with profound weakness and signs of shock, associated with vomiting, diarrhoea and urticaria (Bleumink, 1979).

The results available to date indicate that both type I (IgE-mediated) and type III (IgG + complement mediated) phenomena may be involved. Several cases of food-allergic reaction have been described which fulfil the criteria of type III reactions: high levels of specific IgG, evidence of complement consumption (decrease of plasma $\mathrm{C}_{3}$ ), delayed onset of symptoms, no intolerance or toxic phenomena. The patients show recurrent vomiting and diarrhoea in combination with gastrointestinal bleeding, failure to thrive, anaemia and protein loss (Freier, 1973; May \& Block, 1978; Bleumink, 1979).

Non-reaginic reactions appear to occur almost exclusively in infants and are transient. The transience may result from the characteristic temporary burst of non-reaginic antibodies to foods when they are first introduced into the diet in early life, particularly with cows' milk.

The coeliac-sprue malabsorption syndrome has been shown to be a glutensensitive enteropathy which is not transient and the pathogenesis has been 
extensively discussed by many authors (for review see Asquith \& Haeney, 1979). Numerous studies of humoral and cellular immunity in coeliac disease reveal impressive changes in immune reactivity. In the majority of the patients with villous atrophy, IgG antibodies to gluten and other dietary proteins are found. It is not unlikely that in some individual cases of coeliac disease, type III reactions lead to secondary phenomena and to aggravation or perpetuation of the ailments. Thus in some patients elimination of cows' milk from the diet has been found to lead to a marked improvement in their condition.

\section{Cell-mediated immune reactions due to epicutaneous contact with food constituents}

Type IV reactions. In addition to symptoms occurring after oral administration of foods, epicutaneous contact with food constituents may also cause adverse reactions. The involved areas are the hands and the arms, sometimes the face and neck or the perioral region. Contact dermatitis attributable to foods and food constituents may be divided into allergic contact dermatitis, toxic contact dermatitis by irritating substances, photoallergic reactions and phototoxic reactions. In photoallergic and phototoxic reactions, u.v. light of wavelengths under $325 \mathrm{~mm}$ is essential for the symptoms to develop. An example of these is the occurrence of phototoxic dermatitis after contact with plants belonging to the family of Umbelliferae which contain furocoumarines (psoralene derivates). The symptoms only develop at skin sites not protected from sunlight.

In allergic contact dermatitis, type IV immunological reactions (also called delayed type phenomena or cell-mediated immune reactions) play a role. An allergic sensitization may be diagnosed by performing epicutaneous tests (patch tests) with small amounts of a series of potential allergens and assessing the reactions after $4^{8-72} \mathrm{~h}$.

Pathogenesis. Reactions occur after epicutaneous contact with low-molecularweight substances which become antigenic on combination via covalent bonds with proteins in the skin. The group that becomes attached is called a haptene. Only few components can act as haptenes (Fig. 2) and it usually takes some hours for haptene-carrier complexes to reach the dermis and blood lymphocytes. After previous contact, some $\mathrm{T}$-lymphocytes are capable of recognizing the allergen. Specific surface receptors bind the haptene-carrier complex and the union causes the cell to secrete the complex substances called lymphokines. At the site of reaction, certain lymphokines dilate small blood vessels while others make the vessels 'leaky' so that fluid and blood cells move into the surrounding tissue and cause swelling. Other factors activate macrophages and cause them to congregate at the site of inflammation, and infiltration by non-sensitized lymphoid cells takes place. The ultimate result is an inflammatory reaction characterized by redness (erethema), swelling, vesicles, scaling and exudation of fluid. This type of reaction takes approximately $4^{8} \mathrm{~h}$ to develop and is commonly referred to as delayed allergy.

Major components involved. Table 4 records the important foods and food constituents capable of inducing contact allergies. The most important of these are 

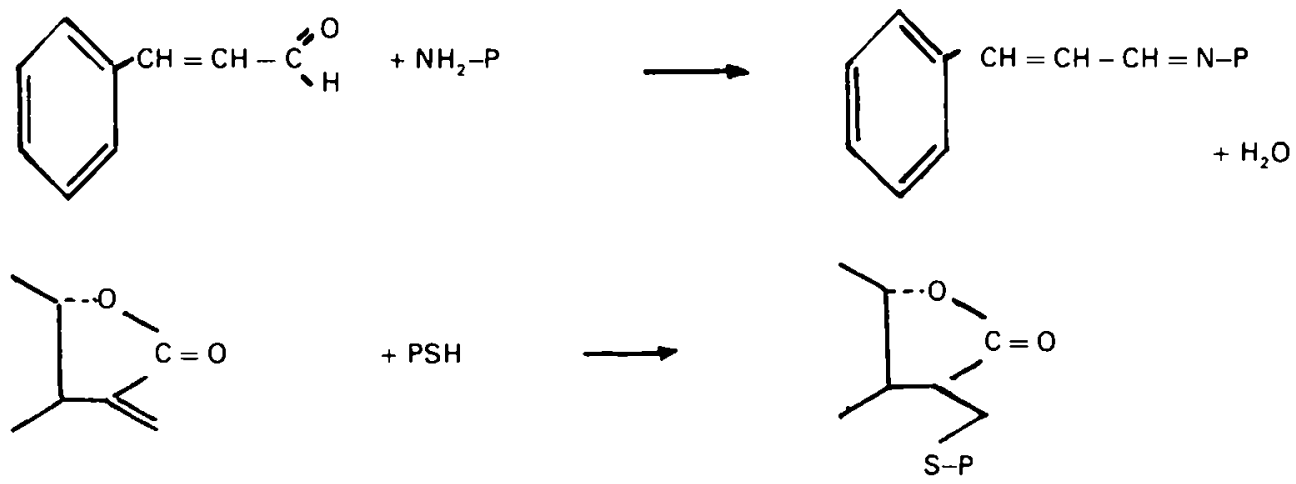

Fig. 2. Low-molecular-weight chemicals conjugate with proteins $(P)$ to become a full-allergen: the haptenic group forms covalent bonds with side chains of the carrier protein.

Top: cinnamic aldehyde (and many other aldehydes) reacts with $\mathrm{NH}_{2}$-groups (for example epsilon-amino-residues of lysine) to form a Schiff-base.

Bottom: alpha-methylene-gamma lactone groups (active residues of many contact allergens of plant origin) react with thiol-groups of proteins by means of a Michael-addition.

garlic, lemons, oranges, cinnamon (cinnamicaldehyde) and vanilla (vanillin and derivatives). Sensitization to the particular substances may occur by contact with foods, but more commonly by contact with the substances present in perfumes, pharmaceuticals, drinks, cosmetics, topical agents, balsams and essential oils of many plants. Persons at risk are bakers and pastry makers (to citrus fruits, flourimprover spices, azo dyes, essential oils), bartenders (to flavouring agents, citrus fruits), workers in the canning industry (to carrots, preservatives), cooks and catering workers (to vegetables, onion, garlic, lemons, spices), workers in the food industry (to spices and vegetables) and housewives and restaurant personnel (to garlic, spices, oranges).

Substances causing reactions by oral contact. In man, type IV alergic phenomena may be elicited after oral contact with low-molecular-weight substances in foods. Jansen (1959), for example, described a case of hypersensitivity to quinine, where sensitization had presumably taken place by skin contact. The patient experienced a shock reaction some $30 \mathrm{~min}$ after the consumption of quinine in tonic water and exacerbation of his eczema the following day. Similar cases have been described (Hjort \& Fregert, 1971; Lockey, 1971). Certain allergic manifestations can also follow the ingestion of food contaminants. Small traces of penicillin in the milk of penicillin-treated cows may provoke allergic reactions (shock and dermatitis) in individuals previously sensitized to this antibiotic by skin contact (nurses) or drug therapy (Welch, 1957; Vickers et al. 1958; Wicher et al. I969; Jaumotte-Istasse, 1975). Similarly, benzoates, added to many foodstuffs as preservatives, may exacerbate eczema in individuals who have a delayed hypersensitivity to compounds of comparable chemical structure present in cosmetics, pharmaceuticals and topically applied medicaments. This is an example of cross-sensitization frequently found in contact 


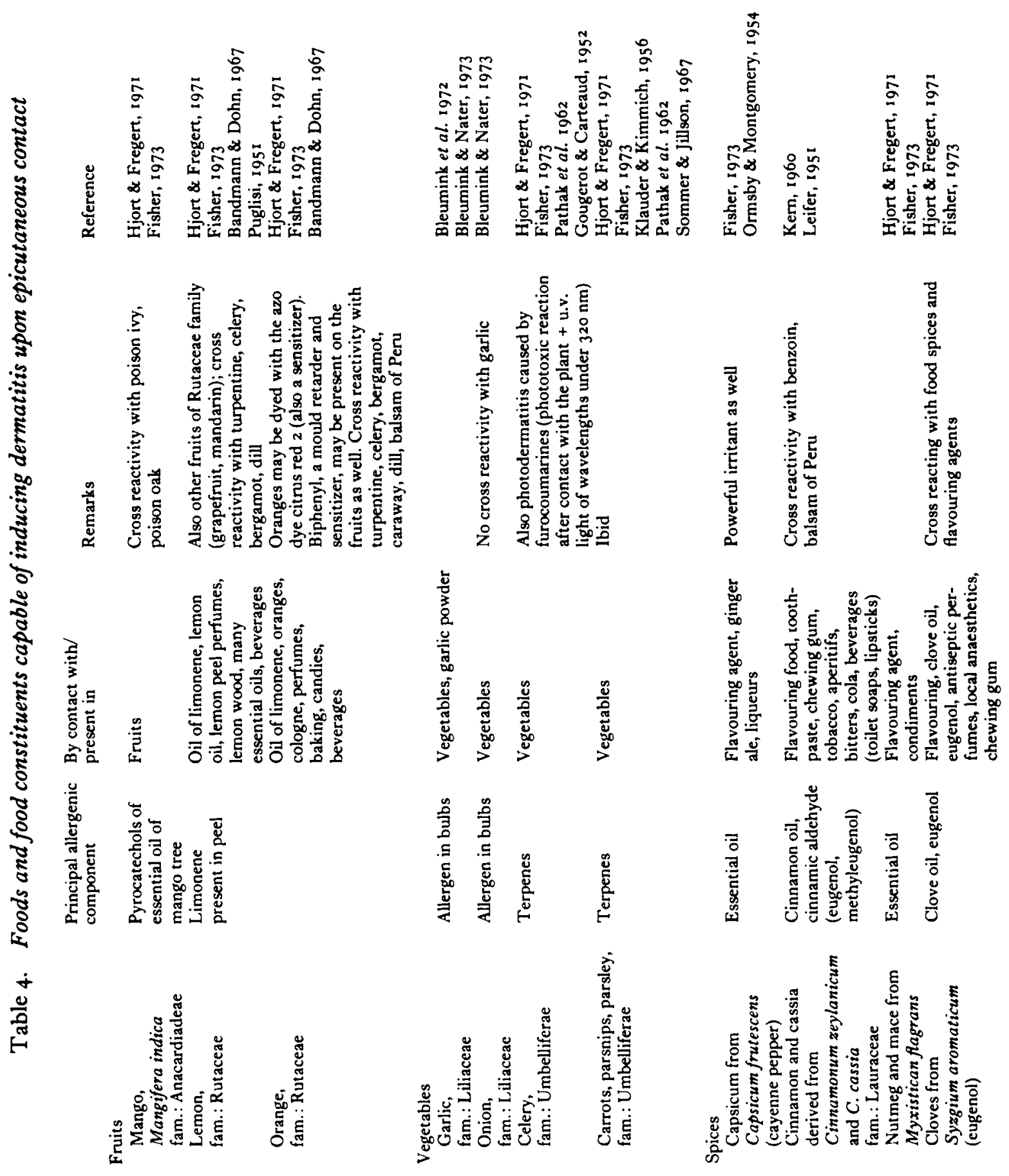




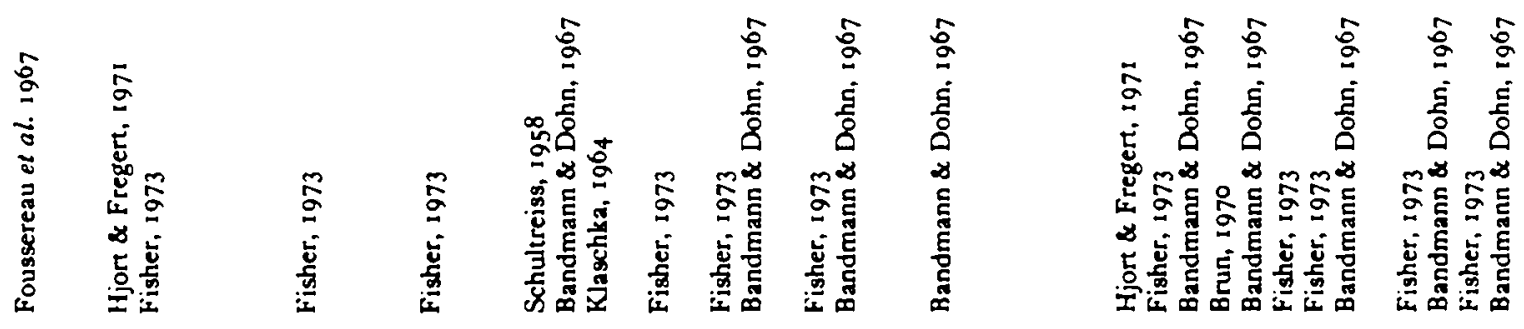

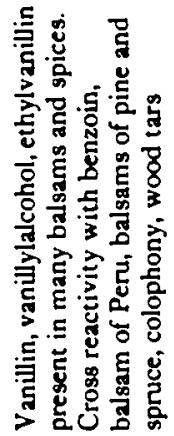
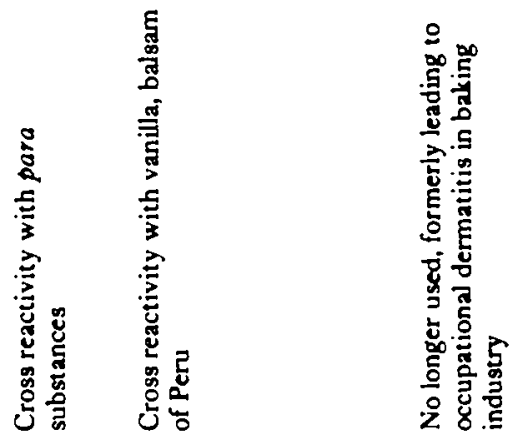

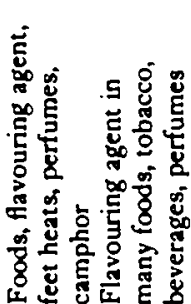

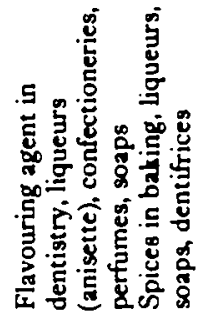

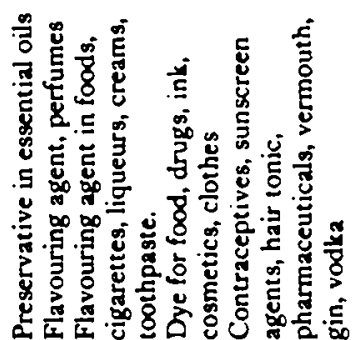

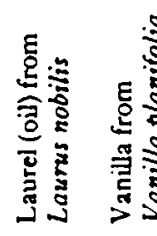

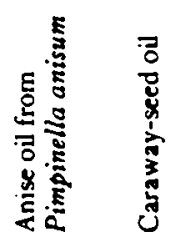

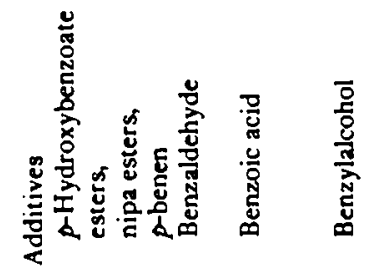

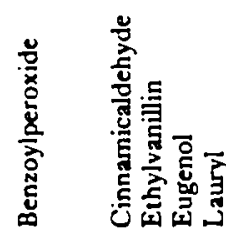

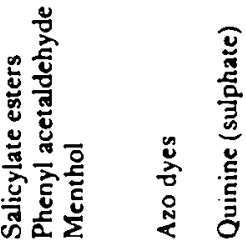


allergy. Persons who have become hypersensitive to $p$-aminobenzoic acid (used in many anti-sunburn lotions) may also show delayed allergic reactions and dermatitis on contact with $p$-hydrobenzoic esters (nipa-esters), $p$-hydrobenzoic acid, benzoic acid and benzoates present in cosmetics, foodstuffs, soaps, soft drinks and medicaments. The following compounds have caused skin reactions such as erythema, eczema, purpura and urticaria after ingestion in previously sensitized persons: mango, garlic, onion, lemon, orange, cinnamon, oil of laurel, $p$ hydroxybenzoate and quinine (Fisher, 1966, 1973; Dang \& Bell, 1967; Hjort \& Fregert, 1971).

Traces of metals, such as chromium, nickel and cobalt, dissolved by cooking acid or salty food in stainless-steel, may cause dermatitis. Adverse reactions following the ingestion of flavours (menthol, salicylates), butylated-hydroxyanisole and butylated-hydroxytoluene, cyclamates, saccharin and the azo dye, tartrazine, are probably not allergenic (Feingold, 1968; Lockey, 1971; Fisherman \& Cohen, 1973; Miller et al. 1974; Doeglas, 1975).

\section{REFERENCES}

Aas, K. (1966). Int. Arch. Allergy Appl. Immunol. 29, 346.

Aas, K. \& Lundkvist, U. (1973). Clin. Allergy 3, 255.

Anderson, A. F. \& Schloss, O. M. (1923). Am. $\mathscr{F}$. Dis. Child. 26, 45 I.

Asquith, P. \& Haeney, M. R. (1979). In Immunology of the Gastrointestinal Tract, p. 66 [P. Asquith, editor], Edinburgh, London and New York: Churchill Livingstone.

Bandmann, H. J. \& Dohn, W. (1967). Die Epicutantestung. München: J. F. Bergman.

Berrens, L. (1971). The Chemistry of Atopic Allergens. Basel: Karger.

Bleumink, E. (1970). World Rev. Nutr. Diet. 12, 505.

Bleumink, E. (1979). In Immunology of the Gastrointestinal Tract, p. 195 [P. Asquith, editor]. Edinburgh, London and New York: Churchill Livingstone.

Bleumink, E., Doeglas, H. M. G., Klokke, A. H. \& Nater, P. J. (1972). Br. F. Dermatol. 87, 6.

Bleumink, E. \& Nater, J. P. (1973). Arch. Derm. Forsch. 247, 117.

Brun, R. (1970). Dermatologica, Basel 140, 390.

Chua, Y. Y., Bremner, K., Lakdawalla, N., Llobet, J. L., Kokubu, H. J., Orange, R. P. \& CollinsWilliams, C. (1976). F. Allergy Clin. Immunol. 58, 299.

Coca, A. F. (1942). In Familial Non-reaginic Food Allergy. Springfield, Illinois: Charles C. Thomas.

Coombs, R. R. A. \& Gell, P. G. H. (1975). In Clinical Aspects of Immunology, 3rd ed., p. 76I [P. G. H. Gell and R. R. A. Coombs, editors]. Oxford: Blackwell Scientific.

Dang, R. W. \& Bell, D. B. (1967). Hawaii Med. F. 27, 149.

Dannaeus, A. \& Inganäs, M. (1981). Clin. Allergy I1, 533 .

Dannaeus, A., Johansson, S. G. O. \& Foucard, T. (1978). Acta Paediatr. Scand. 67, 497.

Dannaeus, A., Johansson, S. G. O., Foucard, T. \& Ohman, S. (1977). Acta Paediatr. Scand. 66, 31 .

Doeglas, H. M. G. (1975). Br. F. Dermatol. 93, 135 .

Feingold, B. F. (1968). Ann. Allergy 26, 309.

Fisher, A. A. (1966). Ann. Allergy 24, 415.

Fisher, A. A. (1973). Contact Dermatitis, 2nd. ed., pp. 243-272. Philadelphia: Lea and Febiger.

Fisherman, E. W. \& Cohen, G. N. (1973). Ann. Allergy 31, I 26.

Freier, S. (1973). Clin. Allergy 3, (suppl), 597.

Fries, J. H. (1982). Ann. Allergy 48, 220.

Foussereau, J., Benezra, Cl. \& Ourisson, G. (1976). Trans. St. Fohns Hosp. Derm. Soc. 53, 141. 
Gerrard, J. W., Mackenzie, J. W. A., Goluboff, N., Garson, J. Z. \& Maningras, C. S. (1973). Acta. Paediatr. Scand. 234, (Suppl), 2.

Gonzalez de la Requera, I., Inigo, J. F. \& Oehling, A. (1971). Dermatologica, Basel 143, 288.

Gougerot, H. \& Carteaud, A. (1952). Les Dermatoses Professionelles, p. I68. Paris: Norbert Malorne.

Halpern, S. R., Sellars, W. A., Johnson, R. B., Anderson, D. W., Superstein, S. \& Reisch, J. G. (1973). F. Allergy Clin. Immunol. 51, 139.

Hedström, V. (1958). Acta Allergol. 12, I53.

Hjort, N. \& Fregert, S. (1971). In Textbook of Dermatology, 2nd ed., vol. 1, p. 305. [A. Rook, editor]. Oxford: Blackwell.

Hoffman, D. R. \& Haddad, Z. H. (1974). F. Allergy Clin. Immunol. 54, I65.

Horesh, A. J. (1972). Ann. Allergy 30,685.

Jansen, L. H. (1959). Ned. T. Geneesk. 103, 1713.

Jaumotte-Istasse, M. Th. (1975). l'Allergie Alimentaire. Leuven: Van der Nauwelaerts.

Kauffman, H. S. \& Frick, O. L. (1981). Clin. Allergy I 1, 549.

Kern, A. B. (1960). Arch. Dermatol. 81, 549.

Klaschka, F. (1964). Z. Haut. Geslechtskr. 37, 312.

Klauder, J. \& Kimmich, J. (1956). Arch. Dermatol. 74, 149.

Lehmus, V. \& Roine, K. (1958). Acta Allergol. 12, 186.

Leifer, W. (195I). Arch. Dermatol. 64, 52.

Lessof, M. H., Wraith, D. G., Merrett, T. G., Merrett, J. \& Buisseret, P. D. (1980). Quart. J. Med., New Series 195, 259.

Lockey, S. D. (1971). Ann. Allergy 29, 471.

Matthew, D. J., Taylor, B., Norman, A. P., Turner, T. W. \& Soothill, J. F. (1977). Lancet i, 321.

May, C. D. \& Alberto, R. (1972). Clin. Allergy 2, 335.

May, C. D. \& Block, S. A. (1978). Allergy 33, 166.

Miller, R., White, L. W. \& Schwartz, H. J. (1974). F. Allergy 53, 240.

Ormsby, O. S. \& Montgomery, O. (1954). Diseases of the Skin, 8th ed, p. 239. Philadelphia: Lea and Febiger.

Parish, W. E. (1971). Clin. Allergy x, 369 .

Pathak, M. A., Daniels, F. Jr \& Fitzpatrick, F. B. (1962). F. Invest. Dermatol. 39, 225.

Prausnitz, C. \& Küstner, H. (1921). Cbl. Bakterial 86, 160.

Puglisi, V. (1951). J. Ital. Derm. 92, 237.

Schultreiss, E. (1958). Berufsdermatosen 6, 292.

Sommer, R. G. \& Jillson, O. F. (1967). New. Engl. F. Med. 276, 1484.

Stanworth, D. R. (1973). Immediate Hypersensitivity. Amsterdam: North Holland Publ. Co.

Taylor, B., Norman, A. P., Orgel, H. A. S., Stokes, C. R., Turner, M. W. \& Soothill, J. F. (1973). Lancet ii, I 12.

Vickers, H. R., Bragatuni, L. \& Alexander, S. (I958). Lancet $i, 35$ I.

Visakorpi, J. K. (1979). In Immunology of the Gastrointestinal Tract, p. 183 [P. Asquith, editor]. Edinburgh, London and New York: Churchill Livingstone.

Welch, H. (1957). Antibiotics Med. 4, 800.

Wicher, K., Reisman, R. E. \& Arbesman, C. E. (1969). J. Am. Med. Assoc. 208, 143.

Wraith, D. G., Merrett, J., Roth, A., Yman, L. \& Merrett, T. G. (1979). Clin. Allergy 9, 25.

Wüthrich, B. \& Schwarz-Speck, M. (1970). Dermatologica, Basel 141, 102. 